To cite this article: Doris Obinyere Obiano, Emeka Ogueri, Ngozi Chima-James \& Irene ljeoma Bernard (2020) Availability and Use of Library Resources in the Rehabilitation of Inmates in Correctional Centers in Imo and Abia States, Nigeria. Information Impact: Journal of Information and Knowledge Management, 11:2, 51-61, DOI: dx.doi.org/10.4314/iijikm.v11i2.5

To link to this article: https://dx.doi.org/10.4314/iijikm.v11i2.5

\title{
Availability and Use of Library Resources in the Rehabilitation of Inmates in Correctional Centers in Imo and Abia States, Nigeria
}

\author{
${ }^{1}$ Doris Obinyere Obiano ${ }^{1}$ Emeka Ogueri ${ }^{1}$ Ngozi Chima-James ${ }^{1}$ Peter O. Moneke ${ }^{1}$ Irene ljeoma \\ Bernard
}

${ }^{1}$ University Library, Federal University of Technology, Owerri, Imo State, Nigeria

\begin{abstract}
The study examined the availability and use of library resources in the rehabilitation of inmates in correctional centers in Imo and Abia states,Nigeria. The study adopted a survey research design using three research questions and three hypotheses. The population of the study comprised 3,854 prisoners from the five prisons in Imo and Abia States, Nigeria. The sample size used was 713 prisoners. Purposive and proportionate random sampling techniques were used. Instruments for the study included: a checklist and a rating scale namely: Availability of Library Resources Checklist (ALRC) and Extent of Use of Library Resources Scale (EULRS). The instruments were validated and found reliable with index of 0.88 for EULRS using Cronbach Alpha Statistic. The research questions were answered using frequency count, proportion, mean and standard deviation while the hypotheses were tested using t-test. The findings were that Owerri and Umuahia correctional centers only have two librarians each in their respective libraries. This implies that the librarians in prison libraries are not adequate. It was also revealed that a good number of resources like fiction books, textbooks, magazines, chairs and lightings were available but some materials like newspapers, newspaper racks, audio cassettes, video tapes, DVD, library software were not found at all but the ones found were utilized to a high extent. Based on these findings, the study recommended among others that the Federal Government should employ more librarians to the correctional services centers in Imo and Abia states so as to reduce job stress and bring information closer to the inmates.
\end{abstract}

Keywords Library Resources, Inmates, Correctional Centers, Rehabilitation 


\section{Introduction}

Given the heterogeneous nature of the society, it is of utmost importance for libraries to identify the various categories of people who make up the society in order to serve their various information needs. There are many definitions and conceptions on what library is, from different authors and scholars. The most simplistic of them all is that it is a collection of books. Modern conceptions however, show that the definition goes beyond this. A holistic definition is that which instills a pragmatic approach of the library as a careful and systematic collection of sources of information, study materials and resources of similar nature, selected by trained experts who in turn are saddled with the duty of making these selected materials easily accessible to a given community for referencing, researching and or borrowing. Library also involves an environment conducive enough to accommodate learners for study and research purposes. A library is established to satisfy the information needs of the people and globally correctional centers are essentially meant for reformation purposes and not just for punishment and maltreatment as are obtainable in them. There are different services rendered in correctional centres in a bid to reform, rehabilitate and reintegrate inmates into the society and the libraries found in these centers help in the achievement of these purposes. Hence, effective library services in the correctional centres are massive tools in soothing the minds and souls of the inmates with optimism to survive outside the four walls of the prison. The prison library plays the same role as a normal library does in the life of a citizen. Visiting prisons for instance in Nigeria, one comes in contact at firsthand with the punitive and tortuous experiences of prisoners. However, with the availability of library resources and usage, inmates in correctional centres may be more useful.

In modern times, the essence of a prison is to institute change in the inmates so that they can become a responsible and law abiding citizen who can contribute meaningfully to the human capacity development and societal growth when he eventually completes his jail term (Campbell, 2006). One of the ways the above aim can be achieved could be by making available relevant library resources in prison libraries which can help in achieving the rehabilitation of the inmates in our correctional homes. However, in Nigeria correctional centres, the inmates seem to be exposed to all forms of abuses instead of engaging them in reformation and reintegration programmes. Some of these abuses include isolation, brutality, violence, stress, physical and psychological victimization, harassment and over-crowding, to mention but a few. Therefore, the study investigates the availability and use of library resources in the rehabilitation of inmates in the correctional centres in Imo and Abia States, Nigeria.

\section{Purpose of the study}

The main purpose of this study was to ascertain the availability and use of library resources in the rehabilitation of inmates in the correctional centers in Imo and Abia States, Nigeria. Specifically, the study also determined the:

- Proportion of available librarians in each of the prison libraries in Imo and Abia States.

- Proportion of material resources available in each of the prison libraries as indicated in the checklist.

- Extent to which the material resources are utilized in each of the prison libraries as rated by the prisoners.

\section{Research questions}

The following research questions will guide this study:

- What is the proportion of available librarians in each of the prison libraries?

- What is the proportion of available material resources in each of the prison libraries as indicated in the checklist? 
- To what extent are the material resources utilized in each of the prison libraries as rated by the prisoners?

\section{Hypotheses}

The following null hypotheses were formulated and will be tested at 0.05 level of significance.

$\mathbf{H O}_{1:}$ There is no significant different between the proportion of available prison librarians in Imo and Abia States.

$\mathbf{H o}_{2}$ : There is no significant difference between the proportions of available prison library material resources in Imo and Abia States, Nigeria.

Ho : There is no significant difference between the mean scores of the prisoners on the extent to which the material resources are utilized in the prison libraries in Imo and Abia States, Nigeria.

\section{Literature review}

Rehabilitation is seen as the reintegration into the society of a convicted person and the main objective of modern penal policy to counter habitual offences. Many attempts have been made to define rehabilitation. Beth, (2014), sees rehabilitation as a central goal of the correctional system which rests on the assumption that inmates can change in moral attitudes and behavior and return to a crime free lifestyle. Rehabilitation is also seen by Onyango, (2013), as a process of curing mental deviation which makes inmates become eligible for work in the society. The modern prison system has never been solely concerned with the deprivation of individual liberty. The prison management and staff have come to the realization that rehabilitation is one of their principal objectives. Therefore, one can categorically state that the purpose of a prison should be the rehabilitation of prisoners for a useful life after jail term.

It is therefore the duty of the court to try $n$ jail those found guilty of various offences while the prison staff take care of the inmates with love and care which will help them to lead a law-abiding and useful lives in custody and after release.

Inmates as well as those in the outside world need information because if you are not informed you are deformed. They need information for several purposes which include helping them to cope with the situations in prison and out of prison. In lieu of the above, Ajogwu (2005) maintained that prisoner's information needs should range from legal needs, health needs, educational needs, vocational needs and financial needs. Inmates in correctional homes equally need information resources to get away from emotional boredom and psychological trauma. They read the materials for recreation and to avoid stress being induced in the prisons due to its unacceptable environment. According to Dike (2002), Inmates improve in their emotional stability and emotional growth through the provision of spiritual and motivational information resources in the prison libraries.

Availability of library resources is defined as ensuring the presence of library resources for immediate use (Abubakar \& Terna, 2007). It is also the condition of being available especially of being accessible or obtainable. Availability of library resources could also be seen as something that can be easily obtained or seen and used. Alokun (2003) affirmed that availability of information is central to human development but insufficient knowledge may create problems resulting in abject poverty, ignorance, hunger, illiteracy etc. However, Omolola (2015) discovered that the information resources available in most prison libraries are books, newspapers and dictionaries. He further stated that the most available retrieval device that facilitates access to information resources is the library catalogue. His discovery is also that books are the most utilized information resources by inmates.

Libraries are engine-rooms and power-houses where information is processed and retrieved for use (Campbell, 2006). The prison libraries are designed to house materials which reflect and support 
training, recreational, vocational and educational activities of the prisoners they serve. Prison libraries acquire library resources in various formats such as prints, non-prints and electronic resources. These resources are acquired using methods such as direct purchase, donations, inter library loans, bequeaths etc. The materials expected in prison libraries include materials on basic education, history, arts, literature and non-book materials. In support of the above, Shirley (2006) reiterates that rehabilitation of inmates in correctional centers has to be dependent on quality library resources since it is the only place incarcerated ones find succor. The above assertion by Shirley gives credence to the fact that poor resources in the library which is also managed unprofessionally with no form of funding support does not augur well for the purpose of imprisonment and rehabilitation.

The word utilization means the act of making use of something or thing for a purpose, so library which is being used for teaching, learning and research purposes is said to be adequately utilized and indispensable. Prout (2009) view the term utilization of all resources as unique although the word is not new. Furthermore the term library utilization refers to the extent of usage of libraries by students and other library clienteles. The library is not just a reservoir of knowledge, information and human experience but it also creates an avenue for accessing the information materials. In view of the above, people make use of the library for academic resources, equipment, assistance and guidance. According to Ugah ( 2008), utilization of library resources stimulates excitement and instills confidence in the users to develop their talents, potentials and capabilities both academically and socially.

In as much as inmates' rehabilitation and re-socialization are on course, there are so many factors which still militate against its objectives. One of them is poor funding of prison libraries and prisons as a whole, poor and dirty prison environment, policies and laws that restrict the type of information materials to be provided to them (Eze, 2013). Due to the strict prison security policies on reading materials, Singer (2000) and Shirley (2003) lamented that many correctional centers' functionaries try to stop some information materials from entering into the centers' library to avoid harmful information that will be detrimental to the security of the centers and the mental health of the inmates. In another development, Dike's findings showed that during the periods when the library was opened regularly by someone with library training and the requisite personal characteristics, usage was very high, users borrowed a wide range of materials, inmates and other staff made use of the library for recreation. Prison library use is also hindered by lack of reading skills and personnel factor.

Another observation was made by Ajanyi and Akinrumji (2004) that there is frustration among readers as a result of their inability to use the library resources. The frustration could be the inability of the library to provide materials that suit their ways of learning. This is why Oyederan (2004) stated that the use of library depends on the availability, accessibility and utilization of the users desired information source. Omagbami and Odunewu (2008) findings showed that prisoners use the library sparingly and the library stock is inadequately managed by non-librarians. Harris as cited by Oyesiku and Oduwole (2004) stated that libraries are instruments of power potent with all the explosive thoughts of mankind. The users of academic libraries are students, staff and faculty members of the institution while the users of prison libraries are inmates and staff of prisons. Clienteles or users of libraries are different in their use of the library just as their programmes are, hence the library user is regarded as the most logical source to determine whether the library is playing its role satisfactorily or not. Eze, (2013) opined that it is impossible for prison libraries to achieve its objective of rehabilitation without provision of library services to prisoners. It is therefore pertinent to say that the prison library is the live-wire of the institution in terms of rehabilitation.

In the opinion of Medina (2000), most inmates lack interest and drive to learn which poses a problem in meeting up the information needs of such prisoners. Some information scientists and other 
writers like London (2000) remarked that a good number of prison library clienteles are not educated and literary types, but they go to the library to relax and may be watch picture books. Staffing of correctional homes' libraries is another major factor which hinders its services to inmates (Becker, 2007). Even if the whole information resources needed are provided, they will not operate themselves. It is the library staff who will make such materials to be meaningful and usable by the inmates. Omagbemi and Odunewu (2008) equally observed that staffing is a major problem in so many prison libraries, which has negative effect on its services to the inmates. Many correctional centers' libraries are understaffed although the American Library Association and IFLA recommended minimum staffing based on size of the inmates population (Shirley, 2006). Some of the correctional centers' libraries operate as one-man manager which is a very wrong practice. This is why Busayo and Elaturoti (2016) study revealed that some of the inmates were not privileged to access the resources of the prison libraries due to lack of adequate staff. Furthermore, in order to enhance the purpose of rehabilitation, Omagbami \& Odunewu, (2008) suggested that library associations should engage in readership promotion campaigns in prisons alongside the prison library staff and also provide training of the library personnel. It is the bad situation in Nigeria prisons that makes prisoners to return back to the society un-rehabilitated. They come out of prison more embittered and hostile than when they were jailed. They tend to form criminal groups in the prison due to lack of information and reading materials in the prison libraries. Uwa (2007) affirmed the above in his article that the inevitably coercive atmosphere of prisons acts as a constraint upon rehabilitation.

\section{Methodology}

Survey research design was adopted for this study. The population for the study comprised of 3,854 prisoners gotten from the five prisons in Imo and Abia states from which a sample of 713 prisoners was drawn comprising 248 prison inmates from Umuahia prison and 465 prisoners from Owerri prison representing $30 \%$ of Umuahia and Owerri prisons population. The researcher made use of two instruments i.e. four-point likert type rating scale and observation checklist for data collection. Descriptive and inferential statistics were used for data analyses. Specifically, frequency count and proportion were used to answer research question one and two. On the inferential statistics, t-test of independent sample proportions statistic was used to test hypotheses one and two at 0.05 level of significance.

\section{Findings}

RQ1: What is the proportion of available librarians in each of the prison libraries in Imo and Abia States?

\section{Hypotheses 1}

$\mathrm{Ho}_{1}$ : There is no significant difference between the proportions of available prison librarians in Imo and Abia States, Nigeria.

Table 1: Results concerning research question 1

\begin{tabular}{|c|c|c|c|c|c|c|c|c|c|}
\hline \multicolumn{4}{|c|}{ Number of librarians in } & \multicolumn{2}{|l|}{$\mathrm{N}$} & \multicolumn{2}{|l|}{$\mathrm{P}$} & & DECISION \\
\hline \multicolumn{4}{|c|}{ Imo state prison (Owerri) } & \multicolumn{2}{|l|}{2} & \multicolumn{2}{|l|}{0.5} & & \\
\hline \multicolumn{4}{|c|}{ Abia state prison ( Umuahia) } & \multicolumn{2}{|l|}{2} & \multicolumn{2}{|l|}{0.5} & & \\
\hline \multicolumn{10}{|c|}{ Hypotheses 1} \\
\hline States & $\mathrm{N}$ & $\mathrm{P}$ & $p$ & $Q$ & $\mathrm{X}$ & $\mathrm{df}$ & $\mathrm{t}_{\text {cal }}$ & \multicolumn{2}{|l|}{$t_{\text {tab }}$} \\
\hline Imo & 2 & 0.5 & 1 & 0 & 0.05 & 2 & 0 & 1.96 & Accept Ho \\
\hline Abia & 2 & 0.5 & & & & & & & Accept Ho \\
\hline
\end{tabular}


The result in table 1 shows the number and proportions of librarians in the sampled prison libraries of the two states. It was indicated in the table that Owerri and Umuahia prisons have two librarians each in their respective library.

The table further revealed that with equal proportion of 0.5 at 0.05 level of significance, $t$-cal of 0 is less than t-tab of 1.96 leading to the acceptance of the null hypotheses, thereby rejecting the alternative hypotheses, concluding that there is no significant difference between the proportion of available prison librarians in Imo and Abia States, Nigeria.

RQ2: What is the proportion of available library material resources in each of the prison libraries as indicated in the observation checklist?

Table 2: Proportion of Available library Material Resources

\begin{tabular}{|c|c|c|c|}
\hline $\mathrm{S} / \mathrm{N}$ & ITEMS & $\begin{array}{l}\text { Number Available in } \\
\text { Owerri Prison }\end{array}$ & $\begin{array}{l}\text { Number available } \\
\text { in Umuahia Prison }\end{array}$ \\
\hline 1 & Typewriter & 1 & 1 \\
\hline 2 & Fiction books & 30 & 22 \\
\hline 3 & Textbooks & 67 & 51 \\
\hline 4 & Reference books & 8 & 6 \\
\hline 5 & Magazines & 56 & 47 \\
\hline 6 & Newspapers & - & 1 \\
\hline 7 & Journals & 16 & 11 \\
\hline 8 & Reading tables & 3 & 4 \\
\hline 9 & Chairs & 68 & 69 \\
\hline 10 & Shelves & 5 & 3 \\
\hline 11 & Newspaper racks & - & - \\
\hline 12 & Magazines Display Cabinet & 1 & - \\
\hline 13 & Computer & 1 & 1 \\
\hline 14 & Audio cassettes & - & - \\
\hline 15 & Phones (GSM) & 4 & 2 \\
\hline 16 & Video Tapes & - & - \\
\hline 17 & Pictures & 6 & 7 \\
\hline 18 & Maps & 2 & - \\
\hline 19 & DVD & - & - \\
\hline 20 & Library software & - & - \\
\hline 21 & Motion Board for Displays & & 31 \\
\hline 22 & Fans & 6 & 2 \\
\hline 23 & Lightings & 51 & 54 \\
\hline 24 & Spacious accommodation & 1 & 1 \\
\hline 25 & TV & 1 & 1 \\
\hline 26 & Internet & - & - \\
\hline 27 & Photocopiers & - & - \\
\hline 28 & Catalogue cards and cabinet & - & - \\
\hline 29 & Bibliographies & 5 & 3 \\
\hline \multirow[t]{2}{*}{30} & Printers & 1 & - \\
\hline & Serial number Available & 21 & 19 \\
\hline
\end{tabular}

Total number of items 
The result in table 2 shows the number of available prison library material resources and the hypotheses showed the proportion of available library materials in the correctional centres in Imo and Abia States. It was indicated in the table that the total number of available library material resources in Owerri and Umuahia prisons are 336 (21) and 287 (19) respectively. It was also indicated that a good number of materials like fiction books, textbooks, magazines, chairs and lightings were available but some materials like newspapers, newspaper racks, audio cassettes, video tapes, DVD, library software were not found at all.

$\mathrm{Ho}_{2}$ : There is no significant difference between the proportions of available prison library material resources in Imo and Abia States, Nigeria

\begin{tabular}{|c|c|c|c|c|c|c|c|c|c|c|c|c|}
\hline States & $T$ & & $n$ & $\mathbf{P}$ & $p$ & & $q$ & $a$ & $d f$ & $t_{c a l}$ & $\boldsymbol{t}_{\mathrm{tab}}$ & Decision \\
\hline Imo & 30 & 21 & 0.70 & 0.67 & 0.33 & 0.05 & 58 & 0.81 & 2.004 & Accep & & \\
\hline Abia & 30 & 19 & 0.63 & & & & & & & Accept & & \\
\hline
\end{tabular}

Expected number of library materials $(\mathbf{N})$, number of Library materials available (n), proportion (p) and ttest statistics of the significance of difference in the proportions

The table further revealed that with proportions of 0.70 and 0.63 , at 0.05 level of significance, $t$-cal of 0.81 is less than t-tab of 2.004 , leading to the acceptance of the null hypothesis, thereby rejecting the alternative hypothesis, and concluding that there is no significant difference between the proportions of available prison library material resources in Imo state and Abia State.

Research question 3: To what extent are the material resources utilized in each of the prison libraries as rated by the prisoners?

Table 3: Extent Material Resources are utilized.

\begin{tabular}{|c|c|c|c|c|c|c|c|}
\hline \multirow[t]{2}{*}{$\mathbf{S} / \mathbf{N}$} & \multirow[t]{2}{*}{ Items Statement } & \multicolumn{3}{|c|}{$\begin{array}{r}\text { Owerri } \\
n=465\end{array}$} & \multicolumn{3}{|c|}{$\begin{array}{c}\text { Umuahia } \\
n=248\end{array}$} \\
\hline & & $\bar{X}$ & $\mathbf{S}$ & Remarks & $\bar{X}$ & $\mathbf{S}$ & Remarks \\
\hline 1 & Typewriter & 2.98 & 1.046 & $\mathrm{HE}$ & 2.89 & 1.135 & $\mathrm{HE}$ \\
\hline 2 & Fiction books & 2.74 & 1.147 & $\mathrm{HE}$ & 2.84 & 1.123 & $\mathrm{HE}$ \\
\hline 3 & Text books & 2.73 & 1.071 & $\mathrm{HE}$ & 2.73 & 1.160 & $\mathrm{HE}$ \\
\hline 4 & Reference books & 2.75 & 1.114 & $\mathrm{HE}$ & 2.66 & 1.190 & $\mathrm{HE}$ \\
\hline 5 & Magazines & 2.84 & 1.056 & $\mathrm{HE}$ & 2.74 & 1.131 & $\mathrm{HE}$ \\
\hline 6 & Journals & 2.62 & 1.218 & $\mathrm{HE}$ & 2.68 & 1.220 & $\mathrm{HE}$ \\
\hline 7 & Reading tables & 2.94 & 1.047 & $\mathrm{HE}$ & 2.79 & 1.112 & $\mathrm{HE}$ \\
\hline 8 & Chairs & 2.85 & 1.106 & $\mathrm{HE}$ & 2.92 & 1.117 & $\mathrm{HE}$ \\
\hline 9 & Shelves & 3.13 & 1.039 & $\mathrm{HE}$ & 3.07 & 1.041 & $\mathrm{HE}$ \\
\hline 10 & Computer & 2.82 & 1.004 & $\mathrm{HE}$ & 2.85 & 1.137 & $\mathrm{HE}$ \\
\hline 11 & Phones(GSM) & 2.66 & 1.156 & $\mathrm{HE}$ & 2.88 & 1.098 & $\mathrm{HE}$ \\
\hline 12 & Pictures & 2.82 & 1.004 & $\mathrm{HE}$ & 2.94 & 1.093 & $\mathrm{HE}$ \\
\hline 13 & $\begin{array}{l}\text { Motion board for } \\
\text { displays }\end{array}$ & 2.85 & 1.107 & $\mathrm{HE}$ & 2.78 & 1.133 & $\mathrm{HE}$ \\
\hline 14 & Fans & 2.89 & 1.063 & $\mathrm{HE}$ & 2.90 & 1.119 & $\mathrm{HE}$ \\
\hline 15 & Lightings & 2.90 & 1.097 & $\mathrm{HE}$ & 3.00 & 1.016 & $\mathrm{HE}$ \\
\hline 16 & $\begin{array}{l}\text { Spacious } \\
\text { accommodation }\end{array}$ & 2.80 & 1.089 & $\mathrm{HE}$ & 2.78 & 1.096 & $\mathrm{HE}$ \\
\hline 17 & TV & 3.8 & .983 & $\mathrm{HE}$ & 3.08 & .970 & $\mathrm{HE}$ \\
\hline
\end{tabular}




\begin{tabular}{|l|l|l|l|l|l|l|l|}
\hline 18 & Bibliographies & 3.03 & 1.088 & HE & 3.09 & 1.043 & HE \\
\hline & $\begin{array}{l}\text { Cluster/Grand } \\
\text { Mean }\end{array}$ & $\mathbf{5 1 . 4 2}$ & & & $\mathbf{5 1 . 6 2}$ & & \\
\hline & Mean of Means & $\mathbf{2 . 8 6}$ & & & $\mathbf{2 . 8 7}$ & & \\
\hline
\end{tabular}

Table 3 above shows the mean ratings of the prisoners in Owerri and Umuahia prisons on the extent to which the material resource are utilized in the prison libraries. The result indicated that all the items (118) were utilized to a high extent. This was so because the mean ratings of the items were greater than the criterion mean of 2.50. The standard deviation shows that the scores in the distribution were not close to each other and thus tending towards the mean. The result therefore implies that material resources are utilized to a high extent.

$\mathrm{Ho}_{3}$ : There is no significant difference between the mean scores of the prisoners on the extent to which the material resources are utilized in the prison libraries in Imo and Abia States, Nigeria.

\begin{tabular}{|l|l|l|l|l|l|l|l|}
\hline \multicolumn{1}{|c|}{ Group } & $\mathbf{N}$ & & & & & & \\
\hline
\end{tabular}

The table above further indicated that the $\mathrm{t}$-cal of 0.352 is less than 1.96 , since $\mathrm{t}$-cal is less than $\mathrm{t}$-tab the null hypothesis will be accepted, leading to the conclusion that there is no significant difference between the extent to which the material resources are utilized in the prison libraries of Imo and Abia States. This implies that the extent to which prisoners in Owerri and Umuahia utilize material resources is not significantly different.

\section{Discussion of Findings}

It was discovered in this study that the correctional centers in Imo and Abia states have only two librarians each in their libraries and when tested it was proved that the number of librarians is not adequate to provide the needed services to the inmates of these correctional centres. This is in consonance with Becker, (2007) result that staffing problem is a major hindrance to library services to prisoners and that even if the library is stocked with all the needed facilities, without the services of adequate and qualified librarians, they would not be meaningful. It is the librarians who will make the information materials to be meaningful to the users. The study also revealed that a good number of material resources like fiction books, textbooks, magazines, chairs and lightings were available but some materials like newspapers, newspaper racks, audio cassettes, video tapes, DVD, library software were not found at all. When tested, it proved that there is no significant difference between the proportions of available prison library material resources in Imo and Abia States. This finding is in consonance with Omolola's (2015) findings which revealed that the information resources available are books, newspapers and dictionaries: the most available retrieval device that facilitates access to information resources is the library catalogue; books were the most utilized information resources by the inmates. Supporting the above finding, Busayo and Elaturoti's (2016) study revealed that $77.4 \%$ of the inmates had access to photocopying services, $76 \%$ had access to inter-library loan services, $56.8 \%$ had access to book loan services and $50.9 \%$ could access past examination questions among others. On the other hand, $50.5 \%$ of the inmates claimed that their cell was far from the prison library, 57.5\% claimed that the general library reading materials were not accessible to them, 59.1\% equally claimed that the prescribed (recommended) textbooks by the West African Examinations Council were not accessible to them and $88.8 \%$ of the inmates claimed that they do 
not have free access to the prison library resources. The similarity in the findings could be linked to the fact there is poor funding of libraries in Nigerian prisons.

The study further revealed that materials resources are utilized to a high extent in Owerri and Umuahia prisons. But when tested, it was confirmed that the extent to which prisoners in Owerri and Umuahia utilize material resources is not significantly different. The reason for this high extent of utilization of these materials is because of the situation which the prisoners are and their conditions in isolation therefore they take solace in utilizing the available material resources. In accordance with this findings, Dike's (2002) findings showed that during the periods when the library was opened regularly by someone with library training and the requisite personal characteristics, usage was very high, users borrowed a wide range of materials, inmates and staff use the library for recreational reading, problems such as lack of reading skills and personnel factor hinder the use of the library. Contrarily, Omagbami and Odunewu (2008) findings showed that prisoners use the library sparingly and the library stock is inadequately managed by non-librarians. The agreements and contradictions among the findings could be attributed to area of the studies.

\section{Conclusion}

It was concluded in this study that prisoners in Imo and Abia State prisons make use of the prison libraries to a high extent but the library collections and librarians are inadequate to serve their information needs. Thus, the extent to which prisoners in Owerri and Umuahia prisons utilize material resources is not significantly different.

\section{Recommendations}

Based on the findings of this study, the following recommendations were made:

--- The Federal government should ensure that correctional centers are well equipped with befitting libraries stocked with current reading materials and other resources to help in the prisoners' rehabilitation and social well being.

--- Adequate provision for qualified librarians needed in the prison libraries in Nigeria should be looked into by the federal government through adherence to public library/UN prison standard and guideline just as it is done in developed countries.

--- From the findings, there is high extent of use of library resources. In order to ensure more adequate utilization of the library materials by inmates, the information needs of prisoners must be known and put into consideration before ordering for books. This will help to cater for their information needs and also draw them closer to the library.

--- Nigerian Library Association should engage the management of correctional centres for collaboration and effective library services in which they can agree to coordinate reading promotion and literacy activities for the inmates.

\section{References}

Abubakar, D. \& Terna, R. (2007). The relationship between availability and use of library resources among academic members of the faculty of environmental science. University of Jos. Nigerian Journal of Library, Archival and Information Science, 1(5), 30-32.

Ajanyi, T. \& Akinrumji, O. (2004). A survey on the use of library resources, services and facilities. Leiden, Netherlands: Scholars Research Library.

Ajogwu, M. (2005). The role of non-governmental organizations (NGO) in providing library and information services to two disadvantaged groups, the blind and the prisoners in Nigeria. 
Unpublished Masters' Degree project of the Department of Library and Information Science, University of Nigeria, Nsukka.

Alokun, N. (2003). Planning and executing library outreach services in Nigeria. Nigeria Libraries, 37(1), 46-50.

Becker, B. W. (2007). Prison library: Providing services to institutional patrons. Available on www.bembecker.com/prisonlibrariesreport.pdf. Retrieved 20/2/20

Beth, M. H. (2014). Rehabilitation - Criminology - Oxford Bibliograhies. Available on https://www.oxfordbibliographies.com. Retrieved 12/5/20

Busayo, I. O. \& Elaturoti, D. F. (2016). Prisons inmates' challenges in accessing library media resources in preparation for Senior School Certificate Examination in Nigeria. Library Philosophy and Practice (e-journal). Available on http://digitalcommons.unl.edu/libphilprac/1373. Retrieved on

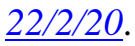

Campbell, D. (2006). The context of the information behavior of prison inmates. Progressive Librarian, 26 (1): 1-12. Available on www.connection.ebscohost.com/.../context information-behaviour. Retrieved 12/1/20.

Dike, V. W. (2002). Prison library services in Nigeria. Journal of Librarianship and Information Science, 2(1), 26-37.

Eze, J. U. (2013). Information needs of prisoners and resources provision through the prison library in South-East zone of Nigeria. An unpublished thesis, University of Nigeria, Nsukka.

London, D. (2000). Conduct for restoration: The prison library. Educational Libraries, 24(1), 21-22.

Medina, D. (2000). The importance of prison libraries. Educational Libraries, 24 (1), 17-19.

Omagbemi, C. and Odunewu, A. (2008). An appraisal of library and information services provision to prison inmates in Nigeria. Information, Society and Justice, 1 (2), 245-254.

Omolola, I. G. (2015). Availability and utilization of information resources for prison inmates in North Central States of Nigeria. IOSR Journal of Humanities and Social Science (IOSR-JHSS), 20, (7), 21-24. Available on www.iosrjournals.org Retrieved 18/12/19

Onyango,O. J. (2013).The challenges facing rehabilitation of prisoners in Kenya and the mitigation strategies. International Journal of Research in Social Sciences, 2 (2), 39-43. Available on http;//scholar.google.com/scholar_url? Retrieved 14/5/20

Oyederan, T. (2004). Information needs and seeking behavior of library users. Result from Yaba College of Technology Lagos. Lagos Journal of Library and Information science, 2 (2), 77-88.

Oyesiku, F. A. \& Oduwole, A. A. (2004). Use of academic library: a survey of Olabisi Onabanjo University. Lagos journal of Library and Information Science, 2 (2), 96-101

Prout, Y. (2009). Online search on utilization of library facilities. Available on http://www.proutworld.org/index.ph? Retrieved 11/12/19 
Shirley, G. (2006). Library services to disadvantaged user groups. LIBREAS-Libraryideas. Available on www.dllr.state.md.us/ce/llb/celibmatarticles.shtml Retrieved 24/2/20

Singer, G. (2000). Prison libraries inside out. Educational Libraries, 24 (1), 11-16

Ugah, D. (2008). Availability and accessibility of information sources and use of library services at Micheal Okpara University of Agriculture, Umudike, Abia State, Nigeria. Library Philosophy and Practice.

Uwa, E. O. (2007). Reading habits of students in the selected tertiary institutions in Imo state. Heartland Journal of Library and Information Science, 1(1), 20-26 